Хірургічна стоматологія

УдК 616.716/4-001-07:611.018.3.-07

DOI 10.11603/2311-9624.2020.1.11218

(CX. Р. Погранична, Р. З. Огоновський, Ю. Б. Пастернак

Львівський національний медичний університет імені Данила Галицького

e-mail: pohranychna@ukr.net

\title{
Комплексна діагностика ушкодження хрящової тканини при захворюваннях скронево-нижньощелепного суглоба травматичного характеру
}

ІНФОРМАЦІЯ

Надійшла до редакціi/Received: 04.11.2019 p.

Ключові слова: скроневонижньощелепний суглоб; хондродеструкція.

\section{АНОТАЦІЯ}

Резюме. Протягом останніх десятиліть спектр діагностики уражених суглобових хрящів надає безліч варіантів розпізнавання, візуалізації, кількісної оцінки та аналізу, пов’язаних із прогресуванням від осередкового ушкодження хряща до розвитку загального захворювання. Точна діагностика ушкодження скронево-нижньощелепних суглобів, особливо їх хрящової тканини, є необхідною умовою для успішного лікування та сприяє покращенню прогнозу в пацієнтів із захворюваннями суглобів різної етіології.

Мета дослідження - запропонувати оновлення та розуміння діагностики суглобових хрящів для клінічних та дослідних цілей, від раннього ураження матриксу та дегенерації до генералізованого внутрішньосуглобового процесу, акцентуючи увагу на надійності, клінічній цінності, поточному стані та можливим застосуванням. Матеріали і методи. Проведено ретроспективний аналіз медичної літератури $з$ порівнянням усіх можливих способів дослідження скронево-нижньощелепних суглобів, у т. ч. клінічні ознаки та симптоми, рентгенографічні дослідження, артроскопію та магнітно-резонансну томографію (МРТ), ультразвукове дослідження, біохімічні показники тощо.

Результати досліджень та їх обговорення. Порівняльний аналіз інструментальних та лабораторних показників довів доцільність застосування найновіший методів діагностики деструкції суглобової хрящової тканини, такі, як уповільнена гадолінієва МРТ хряща, оптична когерентна томографія та генетичне профілювання, що стосуються різних аспектів морфології та функціонування хряща. А можливість визначення маркерів ушкодження хрящової тканини та їх кореляція з іншими показниками дозволяє з аргументованою впевненістю діагностувати усі скронево-нижньощелепні розлади та планувати адекватне лікування.

Висновки. Різноманітні методи діагностики захворювань скронево-нижньощелепного суглоба засновані на візуалізації, біохімічних та біомеханічних характеристиках суглобового хряща. Очікується, що технічне удосконалення та розширення знань про початок та динаміку захворювання позитивно впливатимуть на сучасні тенденції у діагностиці методики та стануть надійною основою для розробки нових лікувальних методик.
Вступ. Точна діагностика ушкодження скронево-нижньощелепних суглобів (СНщС), а особливо їх хрящової тканини, є необхідною умовою для успішного лікування та сприяє покращенню прогнозу в пацієнтів із захворюваннями суглобів різної етіології. Для визначення діагностичної цінності та майбутнього потенціалу певного діагностичного заходу 
необхідно визначити доцільність його застосовування на різних стадіях захворювання. Процес від ушкодження хрящової основи до хондральної дегенерації являє собою перебіг захворювання, при якому зворотність нанесеного ушкодження змінюється залежно від стадії захворювання. Вважається, що цей процес ініціюється змінами у живленні унаслідок склерозу підлеглої кістки та/або мікроушкодження через біомеханічне (над)навантаження. Повторювані незначні ушкодження (порушення оклюзії, больова дисфункція) та одноразові сильні травми (удар, падіння, контузія) пришвидшують розвиток ушкодження основи суглобового хряща [1]. Таким чином, активні молоді люди наражаються на ранній початок дегенерації хряща ще в середньому віці [2]. На ранніх стадіях після ушкодження хряща втрата протеогліканів і порушення колагенної сітки призводять до порушення біомеханіки матриці, що характеризується пом'якшенням тканин. Пом'якшений суглобовий хрящ має знижену здатність чинити опір і передавати ударні сили під час фізіологічного навантаження, спричиняючи поверхневу фібриляцію та тріщини [3]. Тривале навантаження ушкодженого хряща негативно впливає на прогресування захворювання і з часом призводить до загальної дегенерації хряща.

Протягом останніх десятиліть спектр діагностики хрящів надає кілька варіантів розпізнавання, візуалізації, кількісної оцінки та аналізу явищ, пов'язаних із прогресуванням від осередкового дефекту хряща до загального захворювання. Актуальним залишається комплексна оцінка та інтерпретація результатів дослідження скронево-нижньощелепних суглобів, а також їх прикладне використання у розпрацюванні та удосконаленні схем лікування.

Метою дослідження було запропонувати оновлення та розуміння діагностики суглобових хрящів для клінічних та дослідних цілей, від раннього ураження матриксу та дегенерації до генералізованого внутрішньосуглобового процесу, акцентуючи увагу на надійності, клінічній цінності, поточному стані та можливим застосуванням.

Матеріали і методи. Ми опрацювали в ретроспективі найсучасніші фахові періодичні видання, монографії, наукові дослідження у галузі медицини, провели порівняльний аналіз усіх можливих способів дослідження скронево-нижньощелепних суглобів, у т. ч. клінічні ознаки та симптоми, рентгенографічні дослідження, артроскопію та магнітнорезонансну томографію (МРТ), ультразвукове дослідження.

Результати досліджень та їх обговорення. Ушкодження фіброзно-хрящових структурних елементів скронево-нижньощелепного суглоба клінічно проявляеться розвитком дистрофічних і дегенеративних або компенсаторно-гіперрегенеративних процесів хрящових поверхонь, що призводить до деформації останніх, їх перфорації, ушкодження кортикальної пластинки суглобової головки. Зміна суглобових поверхонь і диска, його зміщення, зсув чи вивих стають причиною зміни їх тканинної структури, а як наслідок, розвиток шумових явищ. Найчастіші скарги, надані пацієнтами, це - свист у вухах, «клацання», крепітація, скутість, порушення функціональності, припухлість та обмеження у відкритті рота - ключові клінічні характеристики ушкодження СНщС. Основною причиною, що спонукає пацієнта звернутися за допомогою, залишається біль. На жаль, точні механізми, за допомогою яких генерується біль при скронево-нижньощелепних розладах, залишаються невідомими та не до кінця вивченими. Існує думка, що ноцицептивні волокна є лише в субхондральній кістковій та суглобовій капсулі, але не в хрящі, тому вважається, що внутрішньосуглобові фактори, що вивільняються 3 кортикальної кістки або синовіальної рідини, спричиняють гіперчутливість пов'язаних структур, таких, як окістя, субхондральної кістки, зв'язок [4]. Супутня внутрішньосуглобова гіпертензія та ішемія унаслідок синовіту також можуть бути іншими джерелами болю. Відомо також, що субхондральна венозна непрохідність, що спричиняє підвищений внутрішньокістковий тиск, пов'язана із серйозними дегенеративними змінами в суглобі й може стати джерелом болю на кінцевій стадії захворювання.

Ще одним характерним симптомом ураження хондро-фіброзних структур СНщС $є$ тимчасова, особливо ранкова, скутість, тривалістю менше 30 хв, на відміну від запальної артропатії [5]. Формування остеофітів, ремоделювання субхондральної кістки та потовщення суглобової капсули - це біологічні зміни, які призводять до функціональних порушень та складнощів із повсякденним життям [6].

Клінічні характеристики кістково-хрящових змін оцінюють декількома класифікація- 
ми та анкетами, зосереджуючи увагу на симптомах, щоденній діяльності якості життя. Вони допомагають описати низку випадків, або рівень успішності втручання [7]. Однак ці класифікації не підходять для діагностики дегенерації хряща. Це зумовлено дуже низькою чутливістю (20-49\%) основних клінічних ознак порівняно 3 рентгенографічними системами оцінювання [8]. Загалом клінічні характеристики ураження суглобового хряща погано відображають реальний ступінь дегенерації.

У щоденній клінічній практиці для діагностики дегенерації хряща на кінцевій стадії зазвичай використовують поєднання клінічних та рентгенографічних характеристик захворювання. Хоча сам хрящ невидимий на звичайній рентгенографії, її використовують для виявлення деяких особливостей захворювання. Діагностика хондральних та м'якотканинних структур СНЩС на комп’юторних томограмах не інформативна через малогабаритність розмірів СНЩС та недостатню контрастність м'якотканинних елементів. Проте Келлгрен та Лоуренс представили першу «рентгенологічну оцінку остеоартрозу», акцентуючи увагу на ураженнях твердих тканин суглоба [9]. Вони описали такі рентгенологічні особливості, як остеофіти, навколосуглобові кістки, звуження суглобового простору, субхондральні псевдокістозні склеротичні ділянки та змінену форму кісткових кінців. У даний час ці рентгенографічні зміни, як правило, прийнято вважати ознаками вираженої дегенерації хряща та ознаками остеоартриту чи остеоартрозу. Незважаючи на велику розбіжність результатів одного та декількох дослідників (8-31 \% упередженість дослідника), шкалу Келлгрена та Лоуренса часто застосовують для індивідуального оцінювання прогресування хвороби пацієнта чи визначення ефекту лікування в клінічних випробуваннях. Нещодавно системи оцінювання рентгенографічного ушкодження хрящів, розроблені Альтманом, Голдом і Нагаосою, надають подальшу підкатегоризацію цих індивідуальних рентгенографічних ознак, а також показують хорошу відтворюваність розбіжності результатів оцінювання [10-12]. Незважаючи на це, кілька досліджень показують слабку та помірну кореляцію між рентгенографічними характеристиками дегенеративних хрящів та фактичним ступенем ураження хряща, визначеним артроскопією [13]. Нові розробки для рентгенографічної оцінки тривалої дегенерації хряща на основі комп’ютерних вимірювань загальноприйнятих рентгенографічних ознак можуть допомогти стандартизувати вимірювання цих ознак, а отже, сформувати цінний інструмент для моніторингу прогресування захворювання або ефекту лікування в клінічних випробуваннях [14]. Ці комп’ютерні вимірювання демонструють добру внутрішньогрупову надійність та кореляцію (кореляції балів коливається від 0,50-0,99) з рентгенографічними системами оцінювання. Однак положення пацієнта впливає на кут зйомки рентгенографічного зображення, а отже, і на комп’ютерні вимірювання рентгенографічних особливостей. Тому ці аналітичні алгоритми можуть спричинити практичні проблеми при подальшому спостереженні за пацієнтами. Хоча оцінювання рентгенографічних характеристик для діагностування остеоартрозу і досі часто застосовують у щоденній практиці, фактичний ступінь дегенерації хряща свідчить про погану кореляцію цих параметрів.

Оскільки клінічні симптоми та рентгенологічні ознаки лише побічно свідчать про ушкодження хряща та його дегенерацію, для прямої візуалізації фактичного ушкодження суглобового хряща є ендоскопічна артроскопія СНЩС. Макроскопічні ознаки ушкодження матриксу, фібриляцію та пом'якшення легко визначають під час артроскопії шляхом огляду поверхні та зондування хряща. Однак недоліком є суб’єктивний характер цих спостережень та інвазивність методу. Намагаючись кількісно оцінити та стандартизувати артроскопічну оцінку ушкодження хрящів, було розроблено декілька систем оцінювання (наприклад Французьке товариство системи оцінювання артроскопії [SFA] та шкали Outerbridge) на основі розміру, ступеня та локалізації ураження хряща [15]. Під час перевірки на точність ці системи демонструють як середню та добре відтворювання розбіжності результатів оцінювання $(0,52-0,62)$ та надійність $(0,66-0,80)$, але як правило, мають більш високе узгодження (81 \% міждослідне узгодження) для тяжких дегенеративних ушкоджень порівняно $з$ проміжними ушкодженнями та ушкодженнями нижчого ступеня (65 \% міждослідне узгодження). Це свідчить про те, що артроскопічне оцінювання може не підходити для кількісної оцінки раннього ураження хряща. Альтернативні макроскопічні системи оцінювання, такі, як Міжнародне товариство 
відновлення хрящів (ICRS) та артроскопічні оцінювання Oswestry (OAS) також були розроблені для забезпечення макроскопічної оцінки регенеративного відновлення хряща [16]. ці системи показали хорошу між- та внутрішньообсерваторну надійність (0,62 та 0,56 ICRS та 0,73 та 0,65 OAS відповідно) і тому їх можна застосовувати для вимірювання результатів у клінічних випробуваннях хрящової регенерації. Оскільки макроскопічне ушкодження, яке видно при артроскопічній оцінці, є радше незворотним, артроскопія схоже $є$ добрим методом оцінювання тяжких осередкових уражень хряща, але має нижчу чутливість до діагностичного аналізу раннього ураження матриці хряща. Водночас, артроскопію СНщС можна використовувати не тільки 3 діагностичною метою, але й як малоінвазивний лікувальний захід для видалення остеофітів, зшивання зв'язок, відновлення меніска під ендоскопічним контролем [12].

Ультразвукова оцінка суглобового хряща перш за все базується на швидкості звуку в хрящі. Товщину суглобового хряща, як свідчення стану тканини, обчислювали за швидкістю та так званим часом польоту. Однак невідповідність швидкості звуку в здоровому (1658-1760 м/c) та ушкодженому (1567-1600 м/с) хрящах сильно впливає на вимірювання товщини [17]. Намагаючись забезпечити біомеханічне кількісне визначення стану хряща, ультразвукові вимірювання поєднувались 3 тестами на стиснення [18]. Однак враховуючи різницю швидкості звуку в хрящі відповідно до стану тканини, що призводить до великих похибок вимірювання товщини та біомеханічних модулів, можливе клінічне застосування цього механічно-акустичного кількісного визначення суглобового хряща може бути спірним [19].

Оскільки складові хрящової матриці впливають на ослаблення та (під) поверхневі відбивання високочастотних ультразвукових хвиль, більш детальна оцінка ультразвукових рефлекторних відлунь була проведена для опису патологічних змін під час ушкодження та дегенерації хрящової матриці [20]. Однак визначені кількісні параметри ультразвуку показали слабку кореляцію з біохімічним підрахунком і зуміли лише відрізнити здорові зразки від сильно вражених [21].

Принцип дії оптичної когерентної томографії (ОКТ), аналогічний до ультразвуку, з різницею в тому, що в ОКТ використовують випромінювання ближнього інфрачервоного світла, а не звукові хвилі. Резолюція цієї методики для суглобового хряща становить від 10 до 15 мкм. Крім того, зображення поперечного розрізу можна отримати на глибині тканини до 2 мм [22]. Показано, що показники гістологічної фібриляції, поверхневої фібриляції, добре співвідносять з індексом фібриляції, який отримано за допомогою ОКТ. Однак незважаючи на те, що ОКТ здатна показати структурні зміни орієнтації та дезорганізації (під) поверхневого колагену, втрата протеоглікану як частина раннього (травматичного) ушкодження матриці, ймовірно не буде виявлена [23]. Ще одне практичне обмеження - вимога розміщення зонда ОКТ точно перпендикулярно поверхні хряща.

Таким чином, і ультразвукове дослідження, і ОКТ дозволяють об'єктивніше вимірювати якість хряща, ніж просте зондування, але дискримінаційну якість у виявленні різних стадій де- або регенерації необхідно перевіряти, щоб дійсно визначити їх додаткову клінічну цінність.

Широкий спектр клінічно доступних та нещодавно розроблених методів магнітно-резонансної томографії (МРТ), системи оцінювання та послідовностей дозволяє проводити ретельний аналіз хряща від вогнищевих уражень до генералізованого захворювання. Поступовість SPGR виробляє високий хрящовий сигнал і низький сигнал від сусідньої суглобової рідини і в даний час є стандартом для кількісної морфологічної візуалізації хряща [24]. Напівкількісні вимірювання об'єму, товщини та площі хряща, отримані за допомогою різних поступовостей сканування, показують найвищу між- та внутрішньообсерваційну надійність та довгострокові помилки у точності від 1,4 до 3,9 \%, що свідчить про привабливість цих параметрів для лонгітудинальних досліджень, спостережень за пацієнтами та діагностичних процедур. Наявність більшого напруження поля до 3Т робить ці вимірювання ще більш точними, похибки точності для 1,5-сильного напруження поля коливаються від 11 до 17 \% і від 3 до 7 \% для напруження поля 3,0 Т [25].

Було розроблено декілька напівкількісних систем оцінювання МРТ для ушкодження хрящовох тканини, орієнтованих на розміри та локалізацію уражень та субхондральні, хрящові, кісткові та меніскальні відхилення. Система оцінювання СНЩС має добре загальне відтворювання (внутрішньокласова коре- 
ляція [ВКК] 0,77), але обмежене відтворювання для хрящової та субхондральної тканини 3 ВКК відповідно 0,64 та 0,63. Загальноорганне узгодження магнітно-резонансної томографії (ЗОУМРТ) є високим, з показником ВКК для хрящової втрати більше ніж 0,90. В цілому ці системи оцінювання забезпечують добру якість для оцінки фіброзно-хрящових структур СНщс. Однак оцінка окремого випадку займе приблизно 45 хв а, отже, обмежує клінічну імплементацію [26].

Хоча системи підрахунків, що існують сьогодні, дозволяють отримати хорошу діагностичну точність середньої та тяжкої дегенерації хрящів, порівняно з рентгенографією, i були розроблені новіші методики, які фокусуються на візуалізації складових хряща як можливих інструментів для виявлення раннього ураження хряща. Деградація колагенової матриці в хрящі підвищує рухомість водних протонів, що можна добре виявити in vivo за допомогою кількісного часу релаксації МРТ Т2. Мобільність протонової води (яка вимірюється кількісною картографією Т2) також схоже відображає архітектуру колагену та щільність суглобового хряща [27].

Методика на основі MPT, dGEMRIC, що дозволяє кількісно визначити протеоглікани, грунтується на негативному заряді (його також називають фіксованою зарядженою щільністю [ФЗЩ]) у хрящі. Введена внутрішньовенно діетилентрамінпентаоцтова кислота (Gd-DTPA) розподіляється у високій концентрації в хрящових ділянках із низьким вмістом протеогліканів і навпаки, тому дозволяє картографувати розподіл протеоглікану в суглобовому хрящі. Ця методика демонструє добре відтворювання in vivo та добрі кореляції (показники кореляції 0,95-0,96) з біохімічно визначеним вмістом протеогліканів in vitro. Зниження сигналу dGEMRIC спостерігають після розриву задньої хрестоподібної зв'язки, порівняно 3 дотравматичним сигналом, що вказує на порушення хрящової матриці після травми коліна. Крім того, були описані значні кореляції між вмістом протеоглікану в синовіальній рідині та сигналом T1GD, у гострій фазі після розриву передньої хрестоподібної зв’язки. Це ілюструє потенціал dGEMRIC для раннього відстеження та подальшого спостереження за захворюваннями [28].

Окрім dGEMRIC, метод T1p MPT також забезпечує кількісну карту розподілу протеогліканів у суглобовому хрящі. Ця методика заснова- на на водно-протеогліканових взаємодіях та змісті. Перевага методу T1 $\rho$ MPT над dGEMRIC полягає в тому, що він не потребує внутрішньовенного введення контрастних агентів. Дослідження in vitro показують сильну кореляцію (коефіцієнт кореляції 0,92-0,98) між вмістом протеогліканів та зміною часу релаксації Т1р [29, 30].

Відома ще одна методика, при якій також використовують ФЗЩ для візуалізації втрати протеоглікану з суглобового хряща, це sodium MPT. Втрата негативно заряджених протеогліканів призводить до зниження ФЗЩ та індукує втрату позитивно заряджених іонів натрію 3 тканини, які можна візуалізувати за допомогою кількісного NaMRI. Цю методику можна використати лише при високому напруженні поля ( $\geq 3 \mathrm{~T})$, але $є$ перспективною для виявлення ранніх втрат протеоглікану з суглобового хряща [31].

Хоча звичайні МРТ-поступовості та системи оцінювання пропонують добрий аналіз усіх структур у суглобах, вони здатні виявити дефект суглобового хряща лише тоді, коли він фактично наявний, що робить їх менш придатними для виявлення порушень хрящової матриці як стадії захворювання, що передує вогнищевим ураженням. Більш новітні експериментальні методи MPT, такі, як dGEMRIC, T1 $\rho$ MPT та sodium MPT, забезпечують перевірене кількісне вимірювання конкретних складових хрящової матриці, що робить їх перспективними інструментами для оцінки раннього ураження суглобового хряща.

Окрім розробки методів візуалізації та артроскопічних приладів для кількісної оцінки ушкодження хрящової матриці та дегенерації на різних стадіях хвороби, досліджено молекулярні маркери ушкодженого та дегенеруючого суглобового хряща у сироватці, сечі та синовіальній рідині для забезпечення більш точних ознак дегенерації хряща [32, 33].

Припускають, що незворотність ушкодження суглобових хрящів збігається 3 фенотиповим зрушенням суглобових хондроцитів. Цей зсув може призвести до невідповідної експресії генів, що кодують складові матриці, й врешті-решт до зниження стабільності матриці. Підвищений рівень кератан сульфату (КС) та олігомерного матричного білка хряща (СОМР) виявлено не тільки у сироватці хворих на рентгенографічний остеоартрит (ОА), але й у сироватці пацієнтів із недавньою суглобовою травмою, наприклад розривом латераль- 
ної зв'язки або механічним ушкодженням меніска [34, 35]. У хворих з травмою суглобів рівень КС у синовіальній рідині та сироватці також був підвищеним. Колагенові неоепітопи в основному використовуються як маркери ураження кістково-хрящових структур суглоба. У пацієнтів із болем у суглобі рівень різних колагенних неоепітопів у сечі та сироватці, породжених розщепленням протеази, серед яких: С-телопептид колагену II типу, неоепітоп розщеплення колагену II типу та неоепітопи розщеплення колагену типу I та II, корелюється 3 вираженням рентгенографічного остеоартриту [36].

Низку показників розглядають як предиктори прогресування хрящової деструкції, на що вказують зміни концентрації матриксних металопротеїназ (МMP-1, MМР-3), С-пептиду проколагену I типу (РІСР), тканинного інгібітора, протеогліканів (PG) та інші матриксні білки, такі, як олігомерний матриксний протеїн хряща (ОМПХ) у синовіальної рідині, сечі та крові пацієнтів [37], і можуть бути оцінені як біохімічні маркери деструкцій хондральних поверхонь СНщС.

Унікальною особливістю будови СНЩС $є$ наявність двох різновидів колагену в його складі - першого і другого типів. У кістковому колагені наявні поперечні зв'язки між окремими молекулами колагену, які відіграють значну роль у його стабілізації, і представлені у вигляді піридиноліну (ПІД) та дезоксипіридиноліну (ДПІД), який є найбільш специфічним для кісткової тканини, оскільки він міститься переважно у колагені I типу. ПІД в основному міститься у колагені II типу в хрящах, зв'язках тощо [38]. ПІД і ДПІД у результаті резорбції колагену не метаболізуються в організмі, а виділяються з сечею. Як засвідчили чисельні літературні джерела, комплекс ПІД і дПІД може слугувати надійним маркером деструкції кісткової та хрящової тканин при травматичних ушкодженнях СНЩС [39, 40].

Також різні цитокіни були залучені до дегенерації хряща під час патологічних процесів у СНЩС. Однак рівні синовіальної рідини більшості запальних цитокінів є низькими або невизначеними, і невідомо якою мірою змінюються рівні цитокінів у сироватці, тому вони $є$ непридатними діагностичними маркерами [41]. При ранній дегенерації суглобів виявлено підвищення рівня інтерлейкіну-1 (IL-1) та інтерлейкіну-6 (IL-6) у сироватці в пацієнтів із розривом меніска та стоншенням хряща. Існує думка, що запальна активність при травматичних ушкодженнях СНЩс зумовлена дисбалансом між прозапальними (інтерлейкін IL-1, IL-6) та протизапальними (інтерлейкін IL-4, IL-10) цитокінами, які відіграють провідну роль у реалізації та підтримці запалення [42]. Ця сфера досліджень все ще потребує вивчення.

Висновки. Різні методи діагностики захворювань хряща засновані на візуалізації, біохімічних та біомеханічних характеристиках суглобового хряща. Очікується, що технічне удосконалення та розширення знань про початок та динаміку захворювання позитивно впливатимуть на сучасні діагностичні методики та є основою для розробки нових методик. Однак необхідно пам'ятати, що можливість точної діагностики стану хряща сама по собі не поліпшить лікування патології хряща на ранніх стадіях, і навіть якщо можна буде розробити нові методи лікування, вони не зможуть застосовуватися до тих пір, поки пацієнт не матиме клінічних ознак, пов'язаних з ушкодженням суглоба. Ці аспекти важливо враховувати при подальшій розробці діагностичних та терапевтичних стратегій у клінічній практиці.

(C)Х. Р. Пограничная, Р. З. Огоновский, Ю. Б. Пастернак

Львовский национальный медицинский университет имени Данила Галицкого

\section{Комплексная диагностика повреждения хрящевой ткани при заболеваниях височно-нижнечелюстного сустава травматического характера}

Резюме. В течение последних десятилетий спектр диагностики пораженных суставных хрящей предоставляет множество вариантов распознавания, визуализации, количественной оценки и анализа, связанных с прогрессированием от очагового повреждения хряща к развитию общего заболевания. Точная диагностика повреждения височно-нижнечелюстных суставов, особенно их хрящевой 


\section{Хірургічна стоматологія}

ткани, является необходимым условием для успешного лечения и способствует улучшению прогноза у пациентов с заболеваниями суставов различной этиологии.

Цель исследования - предложить обновление и понимание диагностики суставных хрящей для клинических и исследовательских целей, от раннего поражения матрикса и дегенерации до генерализованного внутрисуставного процесса, акцентируя внимание на надежности, клинической ценности, текущем состоянии и возможным применением.

Материалы и методы. Проведен ретроспективный анализ медицинской литературы по сравнением всех возможных способов исследования височно-нижнечелюстных суставов, в т.ч. клинические признаки и симптомы, рентгенографические исследования, артроскопию и магнитно-резонансную томографию (МРТ), ультразвуковое исследование, биохимические показатели и тому подобное.

Результаты исследований и их обсуждение. Сравнительный анализ инструментальных и лабораторных показателей доказал целесообразность применения новейших методов диагностики деструкции суставной хрящевой ткани, такие, как замедленная гадолиниева МРТ хряща, оптическая когерентная томография и генетическое профилирование, касающихся различных аспектов морфологии и функционирования хряща. А возможность определения маркеров повреждения хрящевой ткани и их корреляция с другими показателями позволяет с аргументированной уверенностью диагностировать все височно-нижнечелюстные расстройства и планировать адекватное лечение.

Выводы. Различные методы диагностики заболеваний височно-нижнечелюстного сустава основаны на визуализации, биохимических и биомеханических характеристиках суставного хряща. Ожидается, что техническое совершенствование и расширение знаний о начале и динамике заболевания положительно влиять на современные тенденции в диагностике методики и станут надежной основой для разработки новых лечебных методик.

Ключевые слова: височно-нижнечелюстной сустав; хондродеструкция.

CKh. R. Pohranychna, R. Z. Ohonovskyi, Yu. B. Pasternak

Danylo Halytskyi Lviv National Medical University

\section{Comprehensive diagnosis of cartilage damage for temporomandibular joint traumatic diseases}

Summary. Over the past decades, the diagnostic spectrum of affected articular cartilage has provided many options for recognition, visualization, quantification and analysis related to the progression from focal cartilage damage to the development of a common disease. Accurate diagnosis of the temporomandibular joints damage, especially cartilage tissue, is a prerequisite for successful treatment and helps to improve the prognosis in patients with joint diseases of various etiologies.

The aim of the study - to offer updates and proper understanding of the articular cartilage diagnosis for clinical and research purposes from early focal matrix damage and degeneration to a generalized intraarticular process, focusing on reliability, clinical value, current condition and possible use.

Materials and Methods. A retrospective analysis of the medical literature was carried out by comparing all possible methods for examination of the temporomandibular joints, including clinical signs and symptoms, x-ray studies, arthroscopy and magnetic resonance imaging (MRI), ultrasound, biochemical parameters, and etc.

Results and Discussion. A comparative analysis of instrumental and laboratory parameters proved the feasibility of the latest methods usage for the diagnosis of articular cartilage degradation, such as delayed gadolinium MRI of cartilage, optical coherence tomography and genetic profiling, relating to various aspects of cartilage morphology and functioning. The ability to identify markers of the cartilage damage and their correlation with other indicators makes it possible to diagnose all temporomandibular disorders with reasonable confidence and plan for adequate treatment.

Conclusions. The variety of the temporomandibular joint diagnostic methods is based on visualization, biochemical and biomechanical characteristics of the articular cartilage. It is expected that technical improvement and expansion of knowledge about the onset and dynamics of the disease will positively influence on current trends in the diagnosis of the technique and will become a reliable basis for the development of new tretment methods.

Key words: temporomandibular joint; chondrodestruction. 


\section{СПИСОК ЛІТЕРАТУРИ}

1. Burr D. B. Anatomy and physiology of the mineralized tissues: role in the pathogenesis of osteoarthrosis / D. B. Burr // Osteoarthritis Cartilage. - 2004. - Vol. 12 (Suppl. A). - P. S20-S30.

2. The long-term consequence of anterior cruciate ligament and meniscus injuries: osteoarthritis / L. S. Lohmander, P. M. Englund, L. L. Dahl, E. M. Roos // Am. J. Sports Med. - 2007. - Vol. 35 (10). - P. 1756-1769. 3. Articular cartilage and osteoarthritis / J. A. Buckwalter, H. J. Mankin, A. J. Grodzinsky // Instr. Course Lect. 2005. - Vol. 54. - P. 465-480.

4. Kidd B. L. Osteoarthritis and joint pain / B. L. Kidd // Pain. - 2006. - Vol. 123 (1-2). - P. 6-9.

5. Development of criteria for the classification and reporting of osteoarthritis: classification of osteoarthritis of the knee. Diagnostic and Therapeutic Criteria Committee of the American Rheumatism Association / R. Altman, E. Asch, D. Bloch [et al.] // Arthritis Rheum. 1986. - Vol. 29 (8). - P. 1039-1049.

6. Brandt K. D. Osteoarthritis / K. D. Brandt, M. Doherty, L. S. Lohmander. 2nd ed New York: Oxford University Press, 2003.

7. Roos E. M. The Knee injury and Osteoarthritis Outcome Score (KOOS): from joint injury to osteoarthritis / E. M. Roos, L. S. Lohmander // Health Qual Life Outcomes. - 2003. - Vol. 1. - P. 64.

8. Clinical classification criteria for knee osteoarthritis: performance in the general population and primary care / G. Peat, E. Thomas, R. Duncan [et al.] // Ann. Rheum. Dis. - 2006. - Vol. 65 (10). - P. 1363-1367.

9. Kellgren J. H. Radiological assessment of osteoarthrosis / J. H. Kellgren, J. S. Lawrence // Ann. Rheum. Dis. - 1957. - Vol. 16 (4). - P. 494-502.

10. Altman R. D. Atlas of individual radiographic features in osteoarthritis, revised / R. D. Altman, G. E. Gold // Osteoarthritis Cartilage. - 2007. - Vol. 15 (Suppl A). - P. A1-A56.

11. Development of a logically devised line drawing atlas for grading of knee osteoarthritis / Y. Nagaosa, M. Mateus, B. Hassan [et al.] // Ann. Rheum. Dis. - 2000. - Vol. 59 (8). - P. 587-595.

12. Radiographic findings of osteoarthritis versus arthroscopic findings of articular cartilage degeneration in the tibiofemoral joint / R. Kijowski, D. G. Blankenbaker, P. T. Stanton [et al.] // Radiology. - 2006. - Vol. 239 (3). P. 818-824.

13. Arthroscopic validation of radiographic grading scales of osteoarthritis of the tibiofemoral joint / R. Kijowski, D. Blankenbaker, P. Stanton [et al.] // AJR Am. J. Roentgenol. - 2006. - Vol. 187 (3). - P. 794-799.

14. Knee Images Digital Analysis (KIDA): a novel method to quantify individual radiographic features of knee osteoarthritis in detail / A. C. Marijnissen, K. L. Vincken, P. A. Vos [et al.] // Osteoarthritis Cartilage. - 2008. Vol. 16 (2). - P. 234-243.

15. Outerbridge R. E. The etiology of chondromalacia patellae. 1961. / R. E. Outerbridge // Clin. Orthop. Relat. Res. - 2001. - Vol. 389. - P. 5-8.

16. International Cartilage Repair Society (ICRS) and Oswestry macroscopic cartilage evaluation scores validated for use in autologous chondrocyte implantation (ACI) and microfracture / M. P. van den Borne, N. J. Raijmakers, J. Vanlauwe [et al.] // Osteoarthritis Cartilage. - 2007. - Vol. 15 (12). - P. 13971402.

17. Ultrasonic characterization of articular cartilage / J. Toyras, H. J. Nieminen, M. S. Laasanen [et al.] // Biorheology. - 2002. - Vol. 39 (1-2). - 161-169.

18. Mechano-acoustic determination of Young's modulus of articular cartilage / S. Saarakkala, R. K. Korhonen, M. S. Laasanen [et al.] // Biorheology. - 2004. - Vol. 41 (3-4). - P. 167-179.

19. Speed of sound in normal and degenerated bovine articular cartilage / J. Toyras, M. S. Laasanen, S. Saarakkala [et al.] // Ultrasound Med. Biol. - 2003. Vol. 29 (3). - P. 447-454.

20. Ultrasound assessment of articular cartilage: analysis of the frequency profile of reflected signals from naturally and artificially degraded samples / C. P. Brown, S. W. Hughes, R. W. Crawford, A. Oloyede // Connect Tissue Res. - 2007. - Vol. 48 (6). - P. 277-285.

21. In-vitro comparison of time-domain, frequencydomain and wavelet ultrasound parameters in diagnostics of cartilage degeneration / E. Kaleva, S. Saarakkala, J. Toyras [et al.] // Ultrasound Med. Biol. 2008. - Vol. 34 (1). - P. 155-159.

22. Determination of characteristics of degenerative joint disease using optical coherence tomography and polarization sensitive optical coherence tomography / T. Xie, S. Guo, J. Zhang [et al.] // Lasers Surg. Med. - 2006. - Vol. 38 (9). - P. 852-865.

23. Huser C. A. Validation of an in vitro single-impact load model of the initiation of osteoarthritis-like changes in articular cartilage / C. A. Huser, M. E. Davies // J. Orthop. Res. - 2006. - Vol. 24 (4). - P. 725-732.

24. Recent advances in MRI of articular cartilage / G. E. Gold, C. A. Chen, S. Koo [et al.] // AJR Am. J. Roentgenol. - 2009. - Vol. 193 (3). - P. 628-638.

25. Volumetric cartilage measurements of porcine knee at 1.5-T and 3.0-T MR imaging: evaluation of precision and accuracy / J. S. Bauer, S. J. Krause, C. J. Ross [et al.] // Radiology. - 2006. - Vol. 241 (2). - P. 399-406.

26. Magnetic resonance observation of cartilage repair tissue (MOCART) for the evaluation of autologous chondrocyte transplantation: determination of interobserver variability and correlation to clinical outcome after 2 years / S. Marlovits, P. Singer, P. Zeller [et al.] // Eur. J. Radiol. - 2006. - Vol. 57 (1). - P. 16-23.

27. Detection of changes in cartilage water content using MRI T2-mapping in vivo / C. Liess, S. Lusse, N. Karger [et al.] // Osteoarthritis Cartilage. - 2002. - Vol. 10 (12). P. 907-913.

28. 2007 Elizabeth Winston Lanier Award Winner. Magnetic resonance imaging of cartilage glycosaminoglycan: basic principles, imaging technique, and clinical applications / M. L. Gray, D. Burstein, Y. J. Kim, A. Maroudas // J. Orthop. Res. - 2008. - Vol. 26 (3). - P. 281-291.

29. Xia Y. Depth-dependent profiles of glycosaminoglycans in articular cartilage by microMRI and histochemistry / Y. Xia, S. Zheng, A. Bidthanapally // J. Magn. Reson. Imaging. - 2008. - Vol. 28 (1). - P. 151157.

30. Quantification of cartilage biomechanical and 
biochemical properties via T1rho magnetic resonance imaging / A. J. Wheaton, G. R. Dodge, D. M. Elliott [et al.] // Magn. Reson. Med. - 2005. - Vol. 54 (5). - P. 1087-1093. 31. Sodium and T1rho MRI for molecular and diagnostic imaging of articular cartilage / A. Borthakur, E. Mellon, S. Niyogi [et al.] // NMR Biomed. - 2006. - Vol. 19 (7). P. 781-821.

32. 23Na MRI accurately measures fixed charge density in articular cartilage / E. M. Shapiro, A. Borthakur, A. Gougoutas, R. Reddy // Magn. Reson. Med. - 2002. Vol. 47 (2). - P. 284-291.

33. Sodium magnetic resonance imaging of proteoglycan depletion in an in vivo model of osteoarthritis / A. J. Wheaton, A. Borthakur, G. R. Dodge [et al.] // Acad. Radiol. - 2004. - Vol. 11 (1). - P. 21-28.

34. Lohmander L. S. Articular cartilage and osteoarthrosis: the role of molecular markers to monitor breakdown, repair and disease / L. S. Lohmander // J. Anat. - 1994. - Vol. 184 (pt 3). - P. 477-492.

35. Chondroitin sulfate epitope (WF6) and hyaluronic acid as serum markers of cartilage degeneration in patients following anterior cruciate ligament injury / D. Pruksakorn, S. Rojanasthien, P. Pothacharoen [et al.] // J. Sci. Med. Sport. - 2009. - Vol. 12 (4). - P. 445-448. 36 . Association of biomarkers with pre-radiographically defined and radiographically defined knee osteoarthritis in a population-based study / J. Cibere, H. Zhang, P. Garnero [et al.] // Arthritis Rheum. - 2009. - Vol. 60 (5). - P. 1372-1380.

37. Molecular markers in the evaluation of autologous chondrocyte implantation / U. Schneider, U. Schlegel, S. Bauer, C. H. Siebert // Arthroscopy. - 2003. - Vol. 19 (4). - P. 397-403.

38. Wadhwa S. TMJ disorders: Future innovations in diagnostics and treatment / S. Wadhwa, S. Kapila // J. Dent. Educ. - 2008. -Vol. 72, No. 8. - P. 930-947.

39. Changes in urinary bone resorption markers (Pyridinoline, Deoxypyridinoline) resulting from experimentally-induced osteoartritis in the temporomandibular joint of rats / M. Imada, K. Tanimoto, S. Ohno [et al.] // Cranio. - 2003. - Vol. 21, No. 1. - P. 38-45.

40. Pohranychna Kh. Early diagnostics of temporomandibular joint structural elements injuries caused by traumatic mandibular bone fractures / Kh. Pohranychna, U. Matolych, A. Stasyshyn // Polish Journal of Surgery. - 2017. - Vol. 89, No. 3. - P. 31-35.

41. Local cytokine profiles in knee osteoarthritis:elevated synovial fluid interleukin-15 differentiates early from end-stage disease / C. R. Scanzello, E. Umoh, F. Pessler, [et al.] // Osteoarthritis Cartilage. - 2009. - Vol. 17 (8). P. 1040-1048.

42. Diagnostic modalities for diseased articular cartilage / J. E. Bekkers, L. B. Creemers, W. J. Dhert, D. B. F. Saris // Cartilage. - 2010. - Vol. 1 (3). - P. 157-164. 43. Utility of urinary pyridinoline and deoxypyridinoline ratio for diagnosis of osteoartritis at temporomandibular joint / K. Tanimoto, S. Ohno, M. Imada [et al.] // Journal of Oral Pathology and Medicine. - 2004. - Vol. 33, No. 4. - P. 218-223.

\section{REFERENCES}

1. Burr, D.B. (2004). Anatomy and physiology of the mineralized tissues: role in the pathogenesis of osteoarthrosis. Osteoarthritis Cartilage, 12 (suppl A), S20-S30.

2. Lohmander, L.S., Englund, P.M., Dahl, L.L., \& Roos, E.M. (2007). The long-term consequence of anterior cruciate ligament and meniscus injuries: osteoarthritis. Am. J. Sports Med., 35 (10), 1756-1769.

3. Buckwalter, J.A., Mankin, H.J., \& Grodzinsky, A.J. (2005). Articular cartilage and osteoarthritis. Instr. Course Lect., 54, 465-480.

4. Kidd, B.L. (2006). Osteoarthritis and joint pain. Pain, 123 (1-2), 6-9.

5. Altman, R., Asch, E., Bloch, D., Bole, G., Borenstein, D., Brandt, K., ..., \& Hochberg, M. (1986). Development of criteria for the classification and reporting of osteoarthritis: classification of osteoarthritis of the knee. Diagnostic and Therapeutic Criteria Committee of the American Rheumatism Association. Arthritis Rheum., 29 (8), 1039-1049.

6. Brandt, K.D., Doherty, M., \& Lohmander, L.S. (2003). Osteoarthritis. 2nd ed New York: Oxford University Press. 7. Roos, E.M., \& Lohmander, L.S. (2003). The Knee injury and Osteoarthritis Outcome Score (KOOS): from joint injury to osteoarthritis. Health Qual Life Outcomes, 1, 64. 8. Peat, G., Thomas, E., Duncan, R., Wood, L., Hay, E., \& Croft, P. (2006). Clinical classification criteria for knee osteoarthritis: performance in the general population and primary care. Ann Rheum Dis., 65 (10), 1363-1367.

9. Kellgren, J.H., \& Lawrence, J.S. (1957). Radiological assessment of osteo-arthrosis. Ann Rheum Dis., 16 (4), 494-502.

10. Altman, R.D., \& Gold, G.E. (2007). Atlas of individual radiographic features in osteoarthritis, revised. Osteoarthritis Cartilage, 15 (suppl A), A1-A56.

11. Nagaosa, Y., Mateus, M., Hassan, B., Lanyon, P., \& Doherty, M. (2000). Development of a logically devised line drawing atlas for grading of knee osteoarthritis. Ann Rheum. Dis., 59 (8), 587-595.

12. Kijowski, R., Blankenbaker, D.G., Stanton, P.T., Fine, J.P., \& De Smet, A.A. (2006). Radiographic findings of osteoarthritis versus arthroscopic findings of articular cartilage degeneration in the tibiofemoral joint. Radiology, 239 (3), 818-824.

13. Kijowski, R., Blankenbaker, D., Stanton, P., Fine, J., \& De, S.A. (2006). Arthroscopic validation of radiographic grading scales of osteoarthritis of the tibiofemoral joint. AJR Am. J. Roentgenol., 187 (3), 794-799.

14. Marijnissen, A.C., Vincken, K.L., Vos, P.A., Saris, D.B., Viergever, M.A., Bijlsma, J.W., ..., \& Lafeber, F.P. (2008). Knee Images Digital Analysis (KIDA): a novel method to quantify individual radiographic features of knee osteoarthritis in detail. Osteoarthritis Cartilage, 16 (2), 234-243.

15. Outerbridge, R.E. (2001). The etiology of chondromalacia patellae. 1961. Clin. Orthop. Relat. Res., 389, 5-8.

16. van den Borne, M.P., Raijmakers, N.J., Vanlauwe, J., Victor, J., de Jong, S.N., Bellemans, J., \& Saris, D.B. (2007). International Cartilage Repair Society (ICRS) 
and Oswestry macroscopic cartilage evaluation scores validated for use in autologous chondrocyte implantation (ACI) and microfracture. Osteoarthritis Cartilage, 15 (12), 1397-1402.

17. Toyras, J., Nieminen, H.J., Laasanen, M.S., Nieminen, M.T., Korhonen, R.K., Rieppo J, ..., \& Jurvelin, J.S. (2002). Ultrasonic characterization of articular cartilage. Biorheology, 39 (1-2), 161-169.

18. Saarakkala, S., Korhonen, R.K., Laasanen, M.S., Toyras, J., Rieppo, J., \& Jurvelin, J.S. (2004). Mechanoacoustic determination of Young's modulus of articular cartilage. Biorheology, 41 (3-4), 167-179.

19. Toyras, J., Laasanen, M.S., Saarakkala, S., Lammi, M.J., Rieppo, J., Kurkijarvi, J., ..., \& Jurvelin, J.S. (2003). Speed of sound in normal and degenerated bovine articular cartilage. Ultrasound Med. Biol., 29 (3), 447-454.

20. Brown, C.P., Hughes, S.W., Crawford, R.W., \& Oloyede, A. (2007). Ultrasound assessment of articular cartilage: analysis of the frequency profile of reflected signals from naturally and artificially degraded samples. Connect Tissue Res., 48 (6), 277-285.

21. Kaleva, E., Saarakkala, S., Toyras, J., Nieminen, H.J., \& Jurvelin J.S. (2008). In-vitro comparison of time-domain, frequency-domain and wavelet ultrasound parameters in diagnostics of cartilage degeneration. Ultrasound Med. Biol., 34(1), 155-159.

22. Xie, T., Guo, S., Zhang, J., Chen, Z., \& Peavy, G.M. (2006). Determination of characteristics of degenerative joint disease using optical coherence tomography and polarization sensitive optical coherence tomography. Lasers Surg. Med., 38 (9), 852-865.

23. Huser, C.A., \& Davies, M.E. (2006). Validation of an in vitro single-impact load model of the initiation of osteoarthritis-like changes in articular cartilage. J. Orthop. Res., 24 (4), 725-732.

24. Gold, G.E., Chen, C.A., Koo, S., Hargreaves, B.A., \& Bangerter, N.K. (2009). Recent advances in MRI of articular cartilage. AJR Am. J. Roentgenol., 193 (3), 628-638.

25. Bauer, J.S., Krause, S.J., Ross, C.J., Krug, R., CarballidoGamio, J., Ozhinsky, E., ..., \& Link, T.M. (2006). Volumetric cartilage measurements of porcine knee at 1.5-T and 3.0-T MR imaging: evaluation of precision and accuracy. Radiology, 241 (2), 399-406.

26. Marlovits, S., Singer, P., Zeller, P., Mandl, I., Haller, J., \& Trattnig, S. (2006). Magnetic resonance observation of cartilage repair tissue (MOCART) for the evaluation of autologous chondrocyte transplantation: determination of interobserver variability and correlation to clinical outcome after 2 years. Eur. J. Radiol., 57 (1), 16-23.

27. Liess, C., Lusse, S., Karger, N., Heller, M., \& Gluer, C.C. Detection of changes in cartilage water content using MRI T2-mapping in vivo. Osteoarthritis Cartilage, 10 (12), 907-913.

28. Gray, M.L., Burstein, D., Kim, Y.J., \& Maroudas, A. (2008). 2007 Elizabeth Winston Lanier Award Winner. Magnetic resonance imaging of cartilage glycosaminoglycan: basic principles, imaging technique, and clinical applications. J. Orthop. Res., 26 (3), 281-291. 29. Xia, Y., Zheng, S., \& Bidthanapally, A. (2008). Depthdependent profiles of glycosaminoglycans in articular cartilage by microMRI and histochemistry. J. Magn. Reson. Imaging, 28 (1), 151-157.

30. Wheaton, A.J., Dodge, G.R., Elliott, D.M., Nicoll, S.B., \& Reddy, R. (2005). Quantification of cartilage biomechanical and biochemical properties via T1rho magnetic resonance imaging. Magn. Reson. Med., 54 (5), 1087-1093.

31. Borthakur, A., Mellon, E., Niyogi, S., Witschey, W., Kneeland, J.B., \& Reddy, R. (2006). Sodium and T1rho MRI for molecular and diagnostic imaging of articular cartilage. NMR Biomed., 19 (7), 781-821.

32. Shapiro, E.M., Borthakur, A., Gougoutas, A., \& Reddy, R. (2002). 23Na MRI accurately measures fixed charge density in articular cartilage. Magn. Reson Med., 47 (2), 284-291.

33. Wheaton, A.J., Borthakur, A., Dodge, G.R., Kneeland, J.B., Schumacher, H.R., \& Reddy, R. (2004). Sodium magnetic resonance imaging of proteoglycan depletion in an in vivo model of osteoarthritis. Acad. Radiol., 11 (1), 21-28.

34. Lohmander, L.S. (1994). Articular cartilage and osteoarthrosis: the role of molecular markers to monitor breakdown, repair and disease. J. Anat., 184 (pt 3), 477 492.

35. Pruksakorn, D., Rojanasthien, S., Pothacharoen, P., Luevitoonvechkij, S., Wongtreratanachai, P., OngChai, S., \& Kongtawelert, P. (2009). Chondroitin sulfate epitope (WF6) and hyaluronic acid as serum markers of cartilage degeneration in patients following anterior cruciate ligament injury. J. Sci. Med. Sport, 12 (4), 445448.

36. Cibere, J., Zhang, H., Garnero, P., Poole, A.R., Lobanok, T., Saxne T, ..., \& Esdaile, J.M. (2009). Association of biomarkers with pre-radiographically defined and radiographically defined knee osteoarthritis in a population-based study. Arthritis Rheum., 60 (5), 13721380.

37. Schneider, U., Schlegel, U., Bauer, S., \& Siebert, C.H. (2003). Molecular markers in the evaluation of autologous chondrocyte implantation. Arthroscopy, 19 (4), 397-403.

38. Wadhwa, S., \& Kapila, S. (2008). TMJ disorders: Future innovations in diaagnostics and treatment. J. Dent. Educ., 72, 8, 930-947.

39. Imada, M., Tanimoto, K., Ohno, S., Sasaki, A., Sugiyama, H., \& Tanne, K. (2003). Changes in urinary bone resorption markers (Pyridinoline, Deoxypyridinoline) resulting from experimentally-induced osteoartritis in the temporomandibular joint of rats. Cranio, 21, 1, 38-45. 40. Pohranychna, Kh., Matolych, U., \& Stasyshyn, A. (2017). Early diagnostics of temporomandibular joint structural elements injuries caused by traumatic mandibular bone fractures. Polish Journal of Surgery, 89, 3, 31-35.

41. Scanzello, C.R., Umoh, E., Pessler, F., az-Torne, C., Miles, T., Dicarlo, E., ..., \& Crow, M.K. (2009). Local cytokine profiles in knee osteoarthritis: elevated synovial fluid interleukin-15 differentiates early from end-stage disease. Osteoarthritis Cartilage, 17 (8), 10401048.

42. Bekkers, J.E., Creemers, L.B., Dhert, W.J., \& Saris, D.B.F. (2010). Diagnostic modalities for diseased articular cartilage. Cartilage, 1 (3), 157-164.

43. Tanimoto, K., Ohno, S., Imada, M., Honda, K., OhnoNakahara, M., Kapila, S., \& Tanne, K. (2004). Utility of urinary pyridinoline and deoxypyridinoline ratio for diagnosis of osteoartritis at temporomandibular joint. Journal of Oral Pathology and Medicine, 33, 4, 218-223. 